W. Margaretten and D. G. McKay have recently investigated 89 cases of haemorrhagic ulceration of the gastrointestinal tract. ${ }^{8}$ In $70 \%$ of cases there was histologically demonstrable thrombosis of the microcirculation, and in those patients with intravascular thrombi there was frank mucosal infarction in addition to the more superficial haemorrhagic lesion. Nearly all the cases of necrotizing entercolitis showed thrombosis. In a third of the cases thrombus was found in the small blood vessels of tissues other than the gastrointestinal tract. Where no microvascular thrombi could be found, there was only haemorrhagic necrosis. Possibly the thrombi had already undergone fibrinolysis, and infarction had been prevented by a timely restoration of the circulation. More than half the patients showed clinical evidence of intravascular clotting in terms of a reduction of clotting factors or platelets.

These findings are of interest in showing the frequency of the lesion and its relation to thrombosis of the smaller blood vessels. Most of Margaretten and McKay's cases had either heart failure or severe acute infections, and they often had prolonged attacks of hypotension. Vasopressor drugs like adrenaline and noradrenaline given during these attacks may have contributed to both the gastrointestinal ischaemia and the intravascular thrombosis. ${ }^{8}$ The use of vasopressor agents in shock is to be deprecated, for they compromise an already inadequate blood supply. The findings in haemorrhagic ulceration of the gastrointestinal tract emphasize this point.

1 Wilson, R., and Qualheim, R. E., Gastroenterology, 1954, 27, 431.

Ende, N., New England fournal of Medicine, 1958, 258, 879.

- Ming, S.-C., and Levitan, R., New England fournal of Medicine, 1960, 263, 59.

- Ming, S.-C., Circulation, 1965, 32, 332.

5 Kay, A. W., Richards, R. L., and Watson, A. J., British fournal of Surgery, $1958,46,45$.

- Freiman, D. G., Circulation, 1965, 32, 329.

7 Bialostozky, D., Contreras, R., Franco-Browder, S., and Tinajeros, C. A., American fournal of Medicine, 1969, 46, 90.

- Margaretten, W., and McKay, D. G., Archives of Internal Medicine, 1971, 127,250 .

\section{Doctors and the Common Market}

The Government's white paper ${ }^{1}$ on the Common Market, published last week after the B.M.f. had gone to press, refers to organized medicine in a single sentence: "Accession to the Community will not alter in any way the National Health Service."

This bleak statement is largely true. There are no reciprocity agreements for medical qualifications within the E.E.C.; there is no uniformity in specialist or postgraduate training, ${ }^{2}$ and there is not even any arrangement for reciprocal benefits for nationals of one member state from the social or health services of another. If Britain joins the $\mathrm{Six}$ it is no more likely that Italian doctors will flood into Manchester than that British doctors would flock to Marseilles. Nevertheless, the policy of the E.E.C. is one of progressive removal of restrictions on the free mobility of its doctors, and for 13 years the Permanent Committee of Doctors of the E.E.C. and the European Union of Specialist Doctors have been talking about ways of achieving this. Should the Government application be successful Britain will have parity of status with the Six in these negotiations, and indeed the B.M.A. will have to take its turn with the other national medical associations in servicing the committees for a year. The pace of the current negotiations is such, however, that it is virtually certain that no binding decisions will be taken before the date from which Britain's membership would start.

Accession to the E.E.C. would not leave medicine totally unaffected. Animal health standards within the community are to be the subject of an expert working group (para 151 of the white paper), and this will have important implications for current British policy on diseases such as brucellosis. Mobility of labour within the community could mean that more Europeans would come here seeking work in the N.H.S.; or lower-paid workers in the Health Service might find better prospects in Europe. Who knows?

The medical professions of the Six were not consulted about the preparation of the original Treaty of Rome in 1957, and the community's medical bodies still have no statutory recognition. The current negotiations have again ignored medicine: but this should not have come as a surprise, since European medical opinion is agreed that during negotiations of this kind "if the price of cauliflowers is right who cares a damn about the doctors?" The United Kingdom and the European Communities, London, H.M.S.O.,
1971. Price 25p.
British Medical fournal, 1971, 2, 665.

\section{Freedom from Amphetamines}

Traditionally doctors in Britain have always jealously guarded their right to prescribe what they thought was best for an individual patient - a right which was strongly asserted some years ago when the Government proposed a total ban on the manufacture and supply of heroin. ${ }^{1}$ Yet with the worldwide increase in drug abuse some revision of this attitude has been necessary. Doctors have accepted the restriction of supply of drugs of addiction to addicts to special treatment centres and to specially licensed doctors. They have also been re-examining the case for the need to prescribe some of these drugs at all-in particular, amphetamine and amphetamine-like compounds. In 1967 the B.M.A. Science Committee set up a working party to study the usefulness, or otherwise, of these compounds. Its report, published a year later, ${ }^{2}$ concluded that they were "drugs with a limited use in modern therapeutics," and recommended that they should be prescribed only for those conditions where no reasonable alternative existed or for the treatment of amphetamine dependence.

At the same time that the working party was studying these questions a brave new venture was started in Ipswich under the enthusiastic guidance of Dr. F. O. Wells. At first a committee representing a wide range of local activities monitored the extent of drug abuse in the area. By 1969 amphetamine abuse was obviously increasing, and the local medical committee recommended a voluntary ban on the prescribing of all products containing the drug. ${ }^{3}$ General practitioners and hospital doctors agreed not to prescribe the drug and local chemists not to stock them; two months after the ban started there was no evidence whatsoever of amphetamine abuse in the Ipswich area.

As a result of publicity about the Ipswich scheme and a resolution at the A.R.M. in $1970,{ }^{4}$ several other areas 